\title{
The Prevalence of Anaplasma phagocytophilum in Questing Ixodes ricinus Ticks in SW Poland
}

\author{
DOROTA KIEWRA $^{1 *}$, GRZEGORZ ZALEŚNY² and ALEKSANDRA CZUŁOWSKA ${ }^{1}$ \\ ${ }^{1}$ Department of Microbial Ecology and Environmental Protection, \\ Institute of Genetics and Microbiology, University of Wroclaw \\ ${ }^{2}$ Department of Invertebrate Systematics and Ecology, Institute of Biology, \\ Wroclaw University of Environmental and Life Sciences
}

Submitted 9 July 2013, revised 4 October 2013, accepted 16 November 2013

\begin{abstract}
Ticks constitute important vectors of human and animal pathogens. Besides the Lyme borreliosis and tick-borne encephalitis, other pathogens such as Babesia spp., Rickettsia spp., and Anaplasma phagocytophilum, are of increasing public health interest. In Poland, as in other European countries, Ixodes ricinus, the most prevalent tick species responsible for the majority of tick bites in humans, is the main vector of A.phagocytophilum. The aim of the study was to estimate the infection level of I. ricinus with A.phagocytophilum in selected districts, not previously surveyed for the presence of this agent. Sampling of questing ticks was performed in 12 forested sites, located in four districts (Legnica, Milicz, Lubań, and Oława) in SW Poland. Altogether, 792 ticks (151 females, 101 males, and 540 nymphs) representing I. ricinus were checked for the presence of A.phagocytophilum. The average infection level was $4.3 \%$, with higher rate reported for adult ticks. The highest percentage of infected adults was observed in Milicz (17.4\%) and the lowest in Oława (6.8\%). The abundance of questing I. ricinus in all examined sites as well as the infection with A. phagocytophilum indicate for the first time the risk for HGA transmission in SW Poland.
\end{abstract}

Ke y words: Anaplasma phagocytophilum, Ixodes ricinus, Poland

\section{Introduction}

The geographical range of tick-borne diseases (TBD), identification of new pathogens, as well as the increase of TBD incidence makes TBD a serious public health problem. Besides Lyme borreliosis and tickborne encephalitis, which are monitored in Poland, other TBD caused by Babesia spp., Rickettsia spp., and Anaplasma phagocytophilum, are of increasing public health interest.

Anaplasma phagocytophilum, a small gram-negative obligate intracellular alfaproteobacteria, is a tick-borne rickettsial bacterium that replicates in mammalian granulocytes but also in the salivary gland and midgut cells of ticks (Rikihisa, 2011). It causes human granulocytic anaplasmosis (HGA), previously known as human granulocytic ehrlichiosis (HGE), but also the disease in horses, dogs, sheep, and cats (Rar and Golovljova, 2011; Severo et al., 2012). HGA is an emerging disease with varying symptoms, from asymptomatic seroconversion to non-specific symptoms like fever, malaise, myalgia and headache, up to fatal disease (Dumler et al., 2005;
Zwoliński et al., 2007; Rar and Golovljova 2011). The majority of confirmed HGA cases, including the first case of HGA recorded in the early 1990s (Rikihisa, 2011), have been reported from the USA. In Europe, the prevalence of HGA infection is significantly lower, although human cases have been accounted for the majority of European countries, including Poland (Tylewska-Wierzbanowska et al., 2001; Grzeszczuk et al., 2009; Rikihisa, 2011).

Anaplasma phagocytophilum DNA has been detected in several species of hard ticks (Ixodes scapularis, I. pacificus, I. spinipalpis, I. ricinus, I. persulcatus, I. trianguliceps, I. ventalloi, I. ovatus, Dermacentor silvarum) in the United States, Europe, and Asia (Rar and Golovljova 2011; Rikihisa, 2011). In Poland, but also all over Europe, I. ricinus, the most prevalent tick species responsible for the majority of tick bites in humans, is the main vector of A.phagocytophilum. I. ricinus has a three-host live cycle: larvae and nymphs feed mostly on small to medium-sized animals, and adults prefer large-sized mammals. Ticks (larvae, nymphs, or adults) acquire A. phagocytophilum from infected hosts

* Corresponding author: D. Kiewra, Department of Microbial Ecology and Environmental Protection, Institute of Genetics and Microbiology, University of Wroclaw; e-mail: dorota.kiewra@microb.uni.wroc.pl 
through a blood meal, and they can maintain the bacterium through subsequent moultings (transstadial passage), but not by transovarial transmission (Rikihisa, 2011). In Europe, a wide range of mammalian species is infected with A. phagocytophilum (Rar and Golovljova, 2011). However, it is worth noting that the zoonosis potential and host infectivity of A.phagocytophilum depend on genetic variations of strain, due to the host tropism of this bacterium (Severo et al., 2012). Thus, humans are susceptible to limited strains only. The wild host reservoir for strains that infect humans (Ap-ha) is poorly known (Massung et al., 2002; Rikihisa, 2011; Michalik et al., 2012).

The aim of the study was to estimate the infection level of I. ricinus with A. phagocytophilum in selected districts of Lower Silesia, SW Poland, not hitherto surveyed for the presence of this agent.

\section{Experimental}

\section{Materials and Methods}

Tick collection. Sampling of questing ticks was performed in 12 forested sites, located in four districts in SW Poland: Lubań (sites: L1, L2, L3), Milicz (M1, M2, M3), Legnica (Leg1, Leg2, Leg3) and Oława (O1, O2, O3). Ticks were collected by flagging method during spring peak of tick activity, from April to June 2011, at least once a month in each site. Collected ticks were placed in plastic tubes and kept in the refrigerator. The identification of species and life instar was carried out in stereomicroscope, based on the key provided by Siuda (1993).

Detection of A. phagocytophilum in I. ricinus ticks. DNA for PCR was extracted from I. ricinus by lysis in ammonium hydroxide (Rijkpema, 1996). The isolates from nymphs and adults were used for the detection of A. phagocytophilum. Due to the predominance of nymphs in the population, the PCR reactions for nymphs were carried out in pools (5 specimens per pool), which increased the representation of this particular instar and reduced the costs of analysis. Thus, for the calculation of the level of infection in nymphs minimal infection rate (MIR) was used (calculated on the assumption that in each positive pool of tested nymphs only one was infected). The procedure was carried out for 30 samples from each of the 12 monitored sites. To estimate the presence of A.phagocytophilum the diagnostic kit (PK24N DNA Gdańsk) was used. The detection was based on amplification of $16 \mathrm{~S}$ rDNA by nested PCR reaction. The reaction was performed in a reaction volume of $50 \mu \mathrm{l}$ containing $42 \mu \mathrm{l}$ Master Mix PCR-OUT for first and PCR-IN for second amplification, $5 \mu \mathrm{l}$ dNTPs mixture, $1 \mu \mathrm{l}$ DNA polymerase TaqNova, and $2 \mu \mathrm{l}$ of the processed tick sample or $2 \mu \mathrm{l}$
PCR product for nested-PCR. The positive control contained Anaplasma DNA from a diagnostic kit, whereas the negative control contained sterile water. The amplification was performed in a BioRad T100 ${ }^{\mathrm{TM}}$ Thermal Cycler. The amplification included initial denaturation for $2 \mathrm{~min}$ at $95^{\circ} \mathrm{C}$, subjected to 40 cycles (for a second reaction 30 cycles) of $30 \mathrm{~s}$ denaturation at $94^{\circ} \mathrm{C}, 30 \mathrm{~s}$ for the annealing reaction at $55^{\circ} \mathrm{C}, 60 \mathrm{~s}$ extension at $72^{\circ} \mathrm{C}$ and final extension for $5 \mathrm{~min}$ at $72^{\circ} \mathrm{C}$. The separation of the nested PCR products was carried out on a $1.5 \%$ agarose gel with the addition of ethidium bromide in the TBE buffer. Product of $546 \mathrm{bp}$ was regarded as a positive result.

Statistical analysis. The results were analysed using STATISTICA v.10 software. The $\chi^{2}$ test, Kruskal-Wallis ANOVA test and Mann-Witheney test were applied. Probability at $\mathrm{p}<0.05$ was regarded as significant.

\section{Results}

In total, 2507 host-seeking ticks (148 larvae, 1314 nymphs, 478 females, and 567 males) identified as Ixodes ricinus were collected in four districts. Ticks were present in each of 12 sites. However, the tick density varied between districts $(H=235.2 ; p<0.01)$ with the highest prevalence in Lubań (Table I). Altogether, 792 I. ricinus ticks ( 151 females, 101 males, and 540 nymphs) were tested for the presence of $A$. phagocytophilum. Infected ticks were found in all districts. The average infection rate was $4.3 \%$. The infection rate in adults was higher than in nymphs $\left(\chi^{2}=37.093\right.$; $\mathrm{p}<0.001)$. The minimum infection rate was $1.3 \%$ in nymphs and $10.7 \%$ in adults (Table II). The highest level of nymph infection was recorded in Legnica district (3.1\%), while no infected nymphs were found in Lubań district. The highest rate of infected adults was found in Milicz (17.4\%) and the lowest one in Oława (6.8\%). However, the differences beetwen districts were not statistically significant, both for nymphs and adults $\left(\chi^{2}=4,321 ; \mathrm{p}=0,229, \chi^{2}=3.547 ; \mathrm{p}=0.314\right.$, respectively). A higher infection rate was observed in females in comparison to males ( $15.2 \%$ and $3.9 \%$ respectively,

Table I

The average density of I. ricinus in four districts in south-western Poland from April to June 2011.

\begin{tabular}{|l|c|c|c|c|}
\hline \multirow{2}{*}{ District } & \multicolumn{5}{|c|}{$\begin{array}{c}\text { The average number of I. ricinus ticks } \\
\text { collected by one person in } 30 \text { min }\end{array}$} \\
\cline { 2 - 5 } & $\mathrm{n}$ & + & $\delta$ & Total \\
\hline Lubań & 26.5 & 4.8 & 4.4 & 35.7 \\
\hline Milicz & 10.2 & 4.8 & 7.2 & 22.2 \\
\hline Legnica & 3.4 & 4.9 & 5.0 & 13.3 \\
\hline Oława & 4.0 & 4.1 & 3.7 & 11.8 \\
\hline
\end{tabular}


Table II

Anaplasma phagocytophilum infected I. ricinus ticks in four districts in south-western Poland in 2011.

\begin{tabular}{|c|c|c|c|c|c|c|c|c|}
\hline \multirow{3}{*}{ District } & \multicolumn{8}{|c|}{ A. phagocytophilum infected I. ricinus ticks } \\
\hline & \multicolumn{2}{|c|}{ nymphs* } & \multicolumn{2}{|c|}{ females } & \multicolumn{2}{|c|}{ males } & \multicolumn{2}{|c|}{ females \& males } \\
\hline & $\begin{array}{l}\text { number } \\
\text { of tested }\end{array}$ & $\begin{array}{c}\text { positive } \\
(\%)\end{array}$ & $\begin{array}{l}\text { number } \\
\text { of tested }\end{array}$ & $\begin{array}{c}\text { positive } \\
\text { (\%) }\end{array}$ & $\begin{array}{l}\text { number } \\
\text { of tested }\end{array}$ & $\begin{array}{c}\text { positive } \\
(\%)\end{array}$ & $\begin{array}{l}\text { number } \\
\text { of tested }\end{array}$ & $\begin{array}{c}\text { positive } \\
(\%)\end{array}$ \\
\hline Lubań & 170 & 0 & 37 & 10.8 & 19 & 5.2 & 56 & 8.9 \\
\hline Milicz & 220 & 1.8 & 23 & 26.1 & 23 & 8.7 & 46 & 17.4 \\
\hline Legnica & 65 & 3.1 & 47 & 17.0 & 30 & 3.3 & 77 & 11.7 \\
\hline Oława & 85 & 1.2 & 44 & 11.4 & 29 & 0 & 73 & 6.8 \\
\hline Total & 540 & 1.3 & 151 & 15.2 & 101 & 3.9 & 252 & 10.7 \\
\hline
\end{tabular}

* nymphs were tested in pools consisting of five specimens

$\left.\chi^{2}=8.037 ; p=0.004\right)$. The highest level of infection in females was found in Milicz and in Legnica districts (26.1\% and $17.0 \%$ respevtively), and the lowest one (10.8\%) - in Lubań district. The infection level in males varied between 0 (Oława district) and 8.7\% (Milicz district). There were no statistically significant differences between the density of adult ticks in districts, and the level of their infection $(Z=-0.282 ; p=0.778)$

\section{Discussion}

The occurrence of questing Ixodes ricinus ticks is a major factor of tick-borne infection in humans. Previous studies on ticks as vectors of pathogens, carried out in Lower Silesia, were focused mainly on the presence of spirochetes of Borrelia burgdorferi s.l., regarded as the etiological agent of Lyme borreliosis (Kiewra, 2005; Kiewra et al., 2002, 2006). Lyme borreliosis is still considered the most common tick-borne disease in the Northern Hemisphere (Stanek et al., 2012). However I. ricinus can harbour also other pathogens (including bacteria, viruses and protozoa) (Franke et al., 2013). Human granulocytic anaplasmosis (HGA) has been recently recognized as a tick-borne emerging disease, which is spread over USA, Europe and Asia. In Europe, the first confirmed case of HGA was reported in 1997, in Slovenia (Petrovec et al., 1997), whereas the first cases of acute human granulocytic ehrlichiosis were described in 2001 in Poland (Tylewska-Wierzbanowska et al., 2001). It is worth noting, that A. phagocytophilum infection can be asymptomatic, and many infections can be unrecognized (Dumbler et al., 2005).

In Poland, questing I. ricinus ticks infected with A. phagocytophilum were found in north, north-eastern, eastern and central-eastern parts of the country (Stańczak et al., 2004; Grzeszczuk et al., 2002, 2004; Tomasiewicz etal., 2004; Wójcik-Fatla et al., 2009; Sytykiewicz et al., 2012). During present studies, the observed abundance of questing ticks in all examined localities in Lower Silesia, and also the infection of I. ricinus with A. phagocytophilum in Legnica, Milicz, Lubań, and Olawa districts, has revealed for the first time the risk for HGA transmission in SW Poland. The prevalence of infected I. ricinus with A. phagocytophilum was $4.3 \%$. Similar level of infections, varying between $2 \%$ and $6 \%$, depending on the area, were recorded in Lower Saxony, Germany (Templin et al., 2013), whereas the one in urban areas of Kosice, Slovakia reached 2.2\% (Vichova et al., 2013), and 2.6\% in Belarus (Reye et al. 2013). As many as $8.7 \%$ questing I. ricinus were found to be infected with A.phagocytophilum in north-eastern Poland (Grzeszczuk et al., 2004), 8.5\% in central-eastern Poland (Sytykiewicz et al., 2012), 13.1\% in mid-eastern Poland (Tomasiewicz et al., 2004), 14\% in northern Poland (Stańczak et al., 2004). During the present studies no significant differences in infection rates between the districts were observed. However, the infection prevalence can depend on a study area and it may also vary depending on the year of study (Grzeszczuk and Stańczak, 2006a). A. phagocytophilum has been found not only in questing ticks but also in ticks removed from human skin. For example, $23.7 \%$ I. ricinus ticks removed from patients in north-eastern Poland were infected (Grzeszczuk and Stańczak, 2006b). A high prevalence of A. phagocytophilum was also detected in engorged ticks from potential reservoir hosts such as roe deer (Overzier et al., 2013). The studies from the territory of Poland have confirmed that roe deer are essential hosts for maintaining Ixodes ticks and tick-borne diseases, including A. phagocytophilum (Welc-Falęciak et al., 2013).

In our study, the percentage of infected females (15.2\%) was almost 4 times higher than in the males (3.9\%). Females were found to be more infected than males also in other parts of Poland (Tomasiewicz et al., 2004; Grzeszczuk, 2006; Grzeszczuk et al., 2002, 2004; Stańczak et al., 2004; Sytykiewicz et al., 2012). A significantly lower positivity rate (1.3\%) was recorded in nymphs compared to adults. Also other authors 
(Tomasiewicz et al., 2004; Grzeszczuk, 2006; Grzeszczuk et al., 2002, 2004; Stańczak et al., 2004; Sytykiewicz et al., 2012) have shown that the nymphs are less infected than adult ticks. The observed tendency may point to the limited role of small mammals in maintaining A.phagocytophilum in examined districts, compared to large-sized mammals. In Europe, A. phagocytophilum strains associated with rodents are transmitted by I. trianguliceps, and not by I. ricinus ticks (Pangracova et al., 2013). Thus, the occurrence of $I$. ricinus is not sufficient to rodent infection with $A$. phagocytophilum. However, I. ricinus can acquire A. phagocytophilum from large-sized mammals like cervids or wild boars, which can play a role as reservoir hosts (Michalik et al., 2009, 2012).

The obtained results confirm that I. ricinus ticks infected with A.phagocytophilum are widespread in Poland and capable of maintaining the A.phagocytophilum circulation in nature. Thus, in diagnosing the tick-borne disease in SW Poland, the possibility of infection with $A$. phagocytophilum should be also taken into account.

\section{Acknowledgments}

This work was suported by the National Science Centre (NCN), Poland (Grant No. N N404 014 740).

\section{Literature}

Dumler J.S., K.S. Choi, J.C. Garcia-Garcia, N.S. Barat, D.G. Scorpio, J.W. Garyu, D.J. Grab and J.S. Bakken. 2005. Human granulocytic anaplasmosis and Anaplasma phagocytophilum. Emerg. Infect. Dis. 11(12): 1828-1834.

Franke J., A. Hildebrandt and W. Dorn. 2013. Exploring gaps in our knowledge on Lyme borreliosis spirochaetes-updates on complex heterogeneity, ecology, and pathogenicity. Ticks Tick Borne Dis. 4(1-2): 11-25.

Grzeszczuk A. 2006. Anaplasma phagocytophilum in Ixodes ricinus ticks and human granulocytic anaplasmosis seroprevalence among forestry rangers in Białystok region. Adv. Med. Sci. 51: 283-286.

Grzeszczuk A., B. Puzanowska and S. Zirako. 2009. Anaplasma phagocytophilum infection in patients with early Lyme borreliosis, erythema migrans, in north-eastern Poland. Clin. Microbiol. Infect. 15 Suppl 2: 17-8.

Grzeszczuk A. and J. Stańczak. 2006a. Highly variable year-to-year prevalence of Anaplasma phagocytophilum in Ixodes ricinus ticks in northeastern Poland: a 4-year follow-up. Ann. NY Acad. Sci. 1078: 309-311.

Grzeszczuk A. and J. Stańczak. 2006b. High prevalence of Anaplasma phagocytophilum infection in ticks removed from human skin in north-eastern Poland. Ann. Agric. Environ. Med. 13(1): 45-48.

Grzeszczuk A., J. Stańczak and B. Kubica-Biernat. 2002. Serological and molecular evidence of human granulocytic ehrlichiosis focus in the Białowieza Primeval Forest (Puszcza Białowieska), northeastern Poland. Eur. J. Clin. Microbiol. Infect. Dis. 21(1): 6-11.

Grzeszczuk A., J. Stańczak, B. Kubica-Biernat, M. Racewicz, W. Kruminis-Łozowska and D. Prokopowicz. 2004. Human anaplasmosis in north-eastern Poland: seroprevalence in humans and prevalence in Ixodes ricinus ticks. Ann Agric Environ Med. 11(1): 99-103.
Kiewra D. 2005. Dynamics of tick populations (Ixodes ricinus L) in Sleza massif and their role as the vectors of Lime boreliosis. (in Polish). Wiad. Parazytol. 51 (2):171-172.

Kiewra D., E. Lonc, M. Głuszkowski and A. Malinowska. 2002. Geoclimatic influence on the prevalence of castor bean tick - Ixodes ricinus (L.). pp. 155-126. (in Polish). In: Buczek A., Błaszak C. (eds). Stawonogi w medycynie. Wydawnictwo Drukarnia LIBER. Lublin: $115-126$

Kiewra D., K. Rydzanicz and E. Lonc. 2006. Prevalence of Borrelia burgdorferi s.l. in Ixodes ricinus collected from five wooded areas in Lower Silesia (Poland). W: Buczek A, Błaszak C. (eds.): Stawonogi. Znaczenie epidemiologiczne. Koliber. Lublin. 183-187.

Massung R.F., M.J. Mauel, J.H. Owens, N. Allan, J.W. Courtney, K.C. Stafford III and T.N. Mather. 2002. Genetic variants of Ehrlichia phagocytophila, Rhode Island and Connecticut. Emerg. Infect. Dis. 8(5): 467-472.

Michalik J., J. Stańczak, S. Cieniuch, M. Racewicz, B. Sikora and M. Dabert. 2012. Wild boars as hosts of human-pathogenic Anaplasma phagocytophilum variants. Emerg. Infect. Dis. 18(6): 998-1001. Michalik J., J. Stańczak, M. Racewicz, S. Cieniuch, B. Sikora, A. Szubert-Kruszyńska and R. Grochowalska. 2009. Molecular evidence of Anaplasma phagocytophilum infection in wild cervids and feeding Ixodes ricinus ticks from west-central Poland. Clin. Microbiol. Infect. 15 Suppl 2: 81-83.

Overzier E., K. Pfister, I. Herb, M. Mahling, G.Jr Böck and C. Silaghi. 2013. Detection of tick-borne pathogens in roe deer (Capreolus capreolus), in questing ticks (Ixodes ricinus), and in ticks infesting roe deer in southern Germany. Ticks Tick Borne Dis. 4(4): 320-328.

Pangracova L., M. Stanko, L. Mosansky, M. Bona, J. Kraljik, B. Vichova, B. Pet'ko and M. Derdakova. 2013. Genetic variability of Anaplasma phagocytophilum and prevalence of Neoehrlichia mikurensis in rodents as reservoir hosts. Program and Abstracts. XII International Jena Symposium on Tick-Borne Diseases. p. 51.

Petrovec M., S. Lotric Furlan, T.A. Zupanc, F. Strle, P. Brouqui, V. Roux and J.S. Dumler. 1997. Human disease in Europe caused by a granulocytic Ehrlichia species. J. Clin. Microbiol. 35(6): 1556-1559. Rar V. and I. Golovljova. 2011. Anaplasma, Ehrlichia, and "Candidatus Neoehrlichia" bacteria: pathogenicity, biodiversity, and molecular genetic characteristics, a review. Infect Genet Evol. 11(8): 1842-1861. Reye A.L., V. Stegniy, N.P. Mishaeva, S. Velhin, J.M. Hübschen, G. Ignatyev and C.P. Muller. 2013. Prevalence of tick-borne pathogens in Ixodes ricinus and Dermacentor reticulatus ticks from different geographical locations in Belarus. PLoS One. 8(1):e54476. doi: 10.1371/journal.pone.0054476.

Rijpkema S., D. Golubic, M. Molkenboer, N. Verbreek-De Kruif and J. Schellekens. 1996. Identification of four genomic groups of Borrelia burgdorferi sensu lato in Ixodes ricinus ticks collected in a Lyme borreliosis endemic region of northern Croatia. Exp. Appl. Acarol. 20, 23-30.

Rikihisa Y. 2011 Mechanisms of obligatory intracellular infection with Anaplasma phagocytophilum. Clin. Microbiol. Rev. 24: 469-489. Severo M.S., K.D. Stephens, M. Kotsyfakis and J.H. Pedra. 2012. Anaplasma phagocytophilum: deceptively simple or simply deceptive? Future Microbiol. 7(6): 719-731.

Siuda K. 1993. Ticks (Acari: Ixodida) of Poland. Part II. Taxonomy and distribution. (in Polish). Warszawa. Polskie Towarzystwo Parazytologiczne.

Stanek G., G.P. Wormser, J. Gray and F. Strle. 2012. Lyme borreliosis. Lancet 379(9814): 461-473.

Stańczak J., R.M. Gabre, W. Kruminis-Łozowska, M. Racewicz and B. Kubica-Biernat. 2004. Ixodes ricinus as a vector of Borrelia burgdorferi sensu lato, Anaplasma phagocytophilum and Babesia microti in urban and suburban forests. Ann. Agric. Environ. Med. 11(1): 109-114. 
Sytykiewicz H., G. Karbowiak, J. Hapunik, A. Szpechciński, M. Supergan-Marwicz, S. Goławska, I. Sprawka and P. Czerniewicz. 2012. Molecular evidence of Anaplasma phagocytophilum and Babesia microti co-infections in Ixodes ricinus ticks in centraleastern region of Poland. Ann. Agric. Environ. Med. 19(1): 45-49. Templin C., B. Marchwald, S. Olbrich and J. Dreesman. 2013. Detection of a new endemic tick species in Lower Saxony, Germany, in the course of a state-wide monitoring of ticks and tick-borne diseases. Program and Abstracts. XII International Jena Symposium on Tick-Borne Diseases: p.138.

Tomasiewicz K., R. Modrzewska, A. Buczek, J. Stańczak and J. Maciukajć. 2004. The risk of exposure to Anaplasma phagocytophilum infection in Mid-Eastern Poland. Ann. Agric. Environ. Med. 11(2): 261-264.

Tylewska-Wierzbanowska S., T. Chmielewski, M. Kondrusik, T. Hermanowska-Szpakowicz, W. Sawicki and K. Sułek. 2001. First cases of acute human granulocytic ehrlichiosis in Poland. Eur. J. Clin. Microbiol. Infect. Dis. 20(3):.196-198.
Vichova B., B. Halkova, L. Pangracova, M. Stanko, M. Bona, L. Mosansky and B. Pet'ko. 2013. Occurrence of ticks (Ixodida) and tick-borne pathogens in urban areas of Kosice city, eastern Slovakia. Program and Abstracts. XII International Jena Symposium on TickBorne Diseases. p.143.

Welc-Falęciak R., J. Werszko, K. Cydzik, A. Bajer, J. Michalik and J.M. Behnke. 2013. Co-infection and genetic diversity of tick-borne pathogens in roe deer from Poland. Vector Borne Zoonotic Dis. 13(5): 277-288.

Wójcik-Fatla A., J. Szymańska, L. Wdowiak, A. Buczek and J. Dutkiewicz. 2009. Coincidence of three pathogens (Borrelia burgdorferi sensu lato, Anaplasma phagocytophilum and Babesia microti) in Ixodes ricinus ticks in the Lublin macroregion. Ann. Agric. Environ. Med. 16(1):151-158.

Zwoliński J., J. Chmielewska-Badora, A. Wójcik-Fatla, E. Cisak, A. Buczek and J. Dutkiewicz. 2007. Human granulocytic anaplasmosis as an emerging problem of public health. Zdr. Publ. 117(2): 213-219. 
